Article

\title{
Biomimetic asymmetric Michael addition reactions in water catalyzed by amino-containing $\beta$-cyclodextrin derivatives
}

\author{
Qingying Zhu a, Haimin Shen b, Zhujin Yang a, Hongbing Ji a,* \\ a School of Chemistry and Chemical Engineering, Sun Yat-sen University, Guangzhou 510275, Guangdong, China \\ ${ }^{\mathrm{b}}$ College of Chemical Engineering, Zhejiang University of Technology, Hangzhou 310014, Zhejiang, China
}

A R T I C L E I N F O

Article history:

Received 11 March 2016

Accepted 24 April 2016

Published 5 August 2016

\section{Keywords:}

$\beta$-Cyclodextrin

Modification

Enantioselective Michael addition

Quantum chemistry calculation

\begin{abstract}
A B S T R A C T
Nine $\beta$-cyclodextrin derivatives containing an amino group were synthesized via nucleophilic substitution from mono(6-O- $p$-tolylsulfonyl)- $\beta$-cyclodextrin and used in asymmetric biomimetic Michael addition reactions in water at room temperature. The mechanism responsible for the moderate activity and enantioselectivity of the $\beta$-cyclodextrin derivatives was explored using nuclear magnetic resonance spectroscopy, namely 2D ${ }^{1} \mathrm{H}$ rotating-frame overhauser effect spectroscopy (ROESY), ultraviolet absorption spectroscopy, and quantum chemical calculations, which provide a useful technique for investigating the formation of inclusion complexes. The effects of the $\mathrm{pH}$ of the reaction medium, the $\beta$-cyclodextrin derivative dosage, the structure of the modifying amino group, and various substrates on the yield and enantioselectivity were investigated. The results indicated that these factors had an important effect on the enantiomeric excess (ee) in the reaction system. Experiments using a competitor for inclusion complex formation showed that a hydrophobic cavity is necessary for enantioselective Michael addition. A comparison of the reactions using 4-nitro- $\beta$-nitrostyrene and 2-nitro- $\beta$-nitrostyrene showed that steric hindrance improved the enantioselectivity. This was verified by the optimized geometries obtained from quantum chemical calculations. An ee of $71 \%$ was obtained in the asymmetric Michael addition of cyclohexanone and 2 -nitro- $\beta$-nitrostyrene, using (S)-2-aminomethylpyrrolidine-modified $\beta$-CD as the catalyst, in an aqueous buffer solution, i.e., $\mathrm{CH}_{3} \mathrm{COONa}-\mathrm{HCl}$ (pH 7.5).
\end{abstract}

(C) 2016, Dalian Institute of Chemical Physics, Chinese Academy of Sciences. Published by Elsevier B.V. All rights reserved.

\section{Introduction}

Enantioselective Michael addition is an asymmetric C-C bond-forming strategy for single-step generation of multiple stereogenic centers [1]. Excellent conversions and enantiomeric excesses (ee) have been achieved in asymmetric syntheses using metal catalysts such as $\mathrm{Cu}, \mathrm{Ca}, \mathrm{Ni}, \mathrm{Co}$, and $\mathrm{Rh}$ [2]. However, the use of metal catalysts in the pharmaceutical industry is restricted to avoid the presence of trace heavy metals in products. Metal-free catalysts for enantioselective Michael additions are therefore important. The use of small organic molecules as catalysts in asymmetric Michael additions [3] is growing because of their low price, and high stability, efficiency, and selectivity; examples are primary amines [4], pyrrolidine derivatives [5], (thio)ureas [6], chiral squaramides [7], binaphthols [8], quinines [9], chiral phosphines [10], ionic liquids [11], and peptides [12]. However, green reactions that use non-toxic and harmless solvents need to be developed. Water is a safe, economical, and environmentally benign solvent, therefore there has been increasing interest in asymmetric organic

\footnotetext{
* Corresponding author. Tel: +86-20-84113658; Fax: +86-20-84113654; E-mail: jihb@mail.sysu.edu.cn This work was supported by the National Natural Science Foundation of China $(21425627,21376279)$. 
reactions in neat aqueous media [13]. Cyclodextrins (CDs) and their derivatives in aqueous systems have been extensively studied as enzyme mimics [14], which can significantly increase the reaction rates and enantioselectivities of various organic transformations.

$\beta$-CD is a cyclic polysaccharide consisting of seven d-glucopyranoside units. It has a hydrophilic outer surface and a hydrophobic inner cavity, which can induce chiral recognition through complex formation with substrates, similar to the action of enzymes, via non-covalent bonds in water [15]. $\beta$-CD modification with catalytic or reactive groups such as catalytic sites or enzyme binding sites could improve its binding ability and enantioselectivity compared with the hydroxyl-containing parent CD [16]. The construction of an asymmetric catalytic center to enable asymmetric reactions to be performed using CDs is the main target in CD catalysis. In recent years, many asymmetric reactions such as reduction [17], oxidation [18], epoxidation [19], aldol reactions [20], Henry reactions [21], and transamination [22] catalyzed by modified CDs have given acceptable yields and poor to high enantioselectivities. The enantioselectivity is greatly influenced by the structure of the modifying group, solvent, and temperature. Michael additions of nitromethane and thiols to chalcones in water, catalyzed by per-6-amino- $\beta$-cyclodextrin, are highly efficient [23] and achieved $68.5 \%$ ee; only $30 \%$ ee was achieved with the unmodified $\beta$-CD using 2-cyclohexenone and octyl maleate with benzenethiol [24].

In our previous studies, use of an $(S)$-2-aminomethylpyrrolidine-modified $\beta$-CD (CD-1) as a chiral base catalyst significantly enhanced the stereoselectivity in asymmetric aldol reactions, achieving $94 \%$ ee [25]. It would be useful to know whether this asymmetric catalytic effect could also be obtained in Michael additions with CD-1 in water. To the best of our knowledge, there are few reports focusing on the asymmetric Michael addition of cyclohexanones to nitroolefins catalyzed by modified CDs in water. Catalysts CD-1 and CD-2 were tested in Michael additions, and CD-3 to CD-9 (Scheme 1) were prepared under identical conditions and used for comparison.

\section{Experimental}

\subsection{Materials and methods}

$\beta$-CD (99\%) was purchased from the Shanghai Boao Biological Technology Co., Ltd, China. $(S)$-Prolinamide, $(R)$-prolinamide, piperazidine, 4-aminopiperidine, 1,2-diaminopropane (racemic), $N, N^{\prime}$-dimethyl-1,2-ethanediamine, $N, N^{\prime}$-dimethyl-1,3-propanediamine, and 4-nitro- $\beta$-nitrostyrene (purity $98 \%$ in all cases) were purchased from the Sahn Chemical Technology Co., Ltd, China. $p$-Toluenesulfonyl chloride, $\mathrm{LiAlH}_{4}$, and 1,3-diaminopropane were purchased from Aladdin. Ethylenediamine and other common reagents were analytical grade. $n$-Hexane and isopropyl alcohol were chromatographically pure grade. All reagents were used as received without further purification, unless otherwise noted.

Nuclear magnetic resonance (NMR) spectra were recorded, using a Bruker Avance III 400 spectrometer, in $\mathrm{CDCl}_{3}$, DMSO- $d_{6}$,

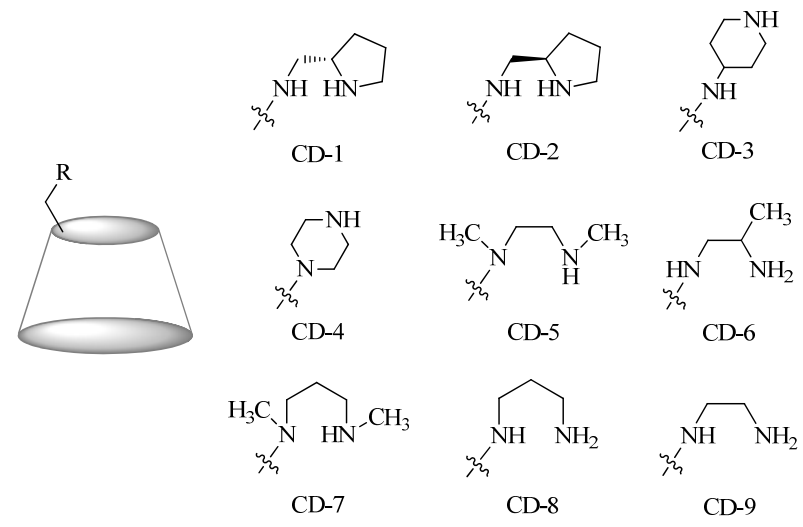

Scheme 1. Supramolecular amino catalysts CD-1 to CD-9.

or $\mathrm{D}_{2} \mathrm{O}$. Tetramethylsilane was used as the internal standard (0.00 ppm) in $\mathrm{CDCl}_{3}$ and DMSO- $d_{6}$, and $\mathrm{H}_{2} \mathrm{O}$ was used as the internal standard ( $4.79 \mathrm{ppm}$ ) in $\mathrm{D}_{2} \mathrm{O}$. The ee was determined by high-performance liquid chromatography (HPLC) using a Shimadzu LC-20AT chromatography system equipped with an ultraviolet (UV)-visible detector and a Chiralcel AS-H or OD-H column, with $n$-hexane and isopropyl alcohol as the eluents. The absolute configuration was determined using HPLC by comparison of the elution sequences of the enantiomers with those of authentic samples and those reported in Ref. [4]. Quantum chemical calculations were performed at the PM3 and B3LYP/6-31G(d) levels using the GAUSSIAN 09 program.

\subsection{Typical procedure for synthesis of CD-1 to $C D-9$}

CD-1 to CD-9 were synthesized according to the procedure reported in Ref. [18]; a representative synthesis is shown in Scheme 2. Nucleophilic substitution of mono(6-O- $p$-tolylsulfonyl)- $\beta$-CD (6.4459 g, $5 \mathrm{mmol}$ ) with the corresponding amine $(25 \mathrm{mmol})$ was performed by reaction in anhydrous dimethylformamide (DMF) at $80{ }^{\circ} \mathrm{C}$ in a nitrogen atmosphere for $24.0 \mathrm{~h}$, followed by cooling to room temperature. $(S)$-Prolinamide and $(R)$-prolinamide were reduced with $\mathrm{LiAlH}_{4}$ to $(S)$-2-aminomethylpyrrolidine and $(R)$-2-aminomethylpyrrolidine.

CD-1: yield 32.5\%; $[\alpha]_{\mathrm{D}}^{25}+138.27\left(c 0.2006, \mathrm{H}_{2} \mathrm{O}\right) ; \mathrm{mp}>240$ ${ }^{\circ} \mathrm{C}$ (decomp.); ${ }^{1} \mathrm{H}$ NMR (400 MHz, $\left.\mathrm{D}_{2} \mathrm{O}\right): \delta(\mathrm{ppm})$ 5.14-4.99 (m, 7H), 3.97-3.68 (m, 24H), 3.61-3.30 (m, 15H), 3.11-3.00 (m, $3 \mathrm{H}), 2.78-2.37(\mathrm{~m}, 5 \mathrm{H}), 1.92-1.43(\mathrm{~m}, 5 \mathrm{H}) ;{ }^{13} \mathrm{C} \mathrm{NMR}(400 \mathrm{MHz}$, DMSO- $\left.d_{6}\right): \delta(\mathrm{ppm}) 164.9,161.2,102.0-101.3(\mathrm{~m}), 84.1,84.0$, 81.6-80.9 (m), 72.8-71.8 (m), 66.0, 63.3, 59.6, 56.3-55.0 (m), 44.4, 27.4, 27.1, 23.3, 23.0; MS (ESI): $m / z 1246\left[M+\mathrm{CH}_{3} \mathrm{CH}_{2}\right]^{+}$, $1218[M+\mathrm{H}]^{+}$.

CD-2: yield 24.2\%; $[\alpha]_{\mathrm{D}}^{25}+143.01$ (c 0.2017, DMF); mp > 250 ${ }^{\circ} \mathrm{C}$ (decomp.); ${ }^{1} \mathrm{H}$ NMR (400 MHz, $\left.{ }_{2} \mathrm{O}\right): \delta$ (ppm) 5.03-4.93 (m,
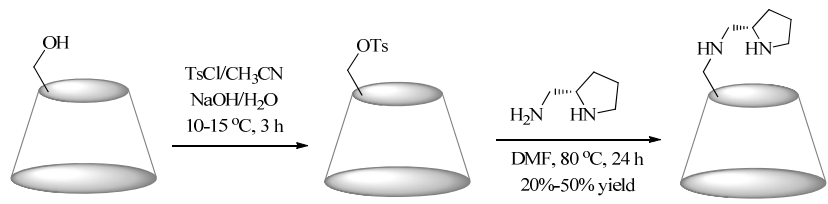

$\beta$-cyclodextrin

Scheme 2. Representative synthesis of supramolecular amino catalysts. 
7H), 3.90-3.68 (m, 23H), 3.56-3.29 (m, 15H), 3.05-2.53 (m, $7 \mathrm{H}), 2.26-2.13(\mathrm{~m}, 1 \mathrm{H}), 1.95-1.36(\mathrm{~m}, 6 \mathrm{H}) ;{ }^{13} \mathrm{C}$ NMR $(400 \mathrm{MHz}$, DMSO-d6): $\delta$ (ppm) 165.6, 161.3, 101.8-101.5 (m), 84.1, 84.0, 81.5-80.8 (m), 72.8-71.7 (m), 69.2, 62.1, 59.7-59.1 (m), 53.9, 53.7, 42.7, 27.0, 22.5; MS (ESI): $m / z 1246\left[M+\mathrm{CH}_{3} \mathrm{CH}_{2}\right]^{+}, 1218$ $[M+\mathrm{H}]^{+}$.

CD-3: yield 54.3\%; $[\alpha]_{\mathrm{D}}^{25}+141.22\left(c 0.2010, \mathrm{H}_{2} \mathrm{O}\right) ; \mathrm{mp}>250$ ${ }^{\circ} \mathrm{C}$ (decomp.); ${ }^{1} \mathrm{H}$ NMR (400 MHz, $\mathrm{D}_{2} \mathrm{O}$ ): $\delta$ (ppm) 5.02-4.95 (m, $7 \mathrm{H}), 3.96-3.72(\mathrm{~m}, 26 \mathrm{H}), 3.57-3.28(\mathrm{~m}, 14 \mathrm{H}), 3.09-2.52(\mathrm{~m}$, $6 \mathrm{H}), 2.30-1.72(\mathrm{~m}, 4 \mathrm{H}), 1.45-1.23(\mathrm{~m}, 2 \mathrm{H}) ;{ }^{13} \mathrm{C}$ NMR $(400 \mathrm{MHz}$, DMSO- $\left.d_{6}\right): \delta(\mathrm{ppm})$ 109.2, 101.9-101.2 (m), 83.6, 81.4-81.0 (m), 72.8-71.7 (m), 70.1, 59.6, 57.5, 53.3, 52.3, 47.8, 34.7, 34.5; MS (ESI): $m / z 1220\left[M+\mathrm{H}_{2}\right]^{+}, 1218[M+\mathrm{H}]^{+}$.

CD-4: yield 64.9\%; $[\alpha]_{\mathrm{D}}^{25}+146.54\left(c 0.2023, \mathrm{H}_{2} \mathrm{O}\right) ; \mathrm{mp}>250$ ${ }^{\circ} \mathrm{C}$ (decomp.); ${ }^{1} \mathrm{H}$ NMR (400 MHz, $\left.\mathrm{D}_{2} \mathrm{O}\right): \delta$ (ppm) 5.01-4.93 (m, $7 \mathrm{H}), 3.97-3.74(\mathrm{~m}, 26 \mathrm{H}), 3.58-3.28(\mathrm{~m}, 16 \mathrm{H}), 2.81-2.72(\mathrm{~m}$, $4 \mathrm{H}), 2.56-2.48(\mathrm{~m}, 4 \mathrm{H}) ;{ }^{13} \mathrm{C}$ NMR (400 MHz, DMSO- $\left.d_{6}\right): \delta(\mathrm{ppm})$ 102.1-101.5 (m), 83.8, 81.7-81.3 (m), 73.1-72.0 (m), 70.3, 70.0, 59.9, 58.4, 57.6, 54.7, 54.3, 53.1, 45.3, 44.9; MS (ESI): $m / z$ $1205\left[M+\mathrm{H}_{2}\right]^{+}, 1203[M+\mathrm{H}]^{+}$.

CD-5: yield 30.1\%; $[\alpha]_{\mathrm{D}}^{25}+148.67\left(c 0.2074, \mathrm{H}_{2} \mathrm{O}\right) ; \mathrm{mp}>240$ ${ }^{\circ} \mathrm{C}$ (decomp.); ${ }^{1} \mathrm{H}$ NMR (400 MHz, $\mathrm{D}_{2} \mathrm{O}$ ): $\delta$ (ppm) 5.06-4.98 (m, 7H), 3.97-3.77 (m, 26H), 3.61-3.51 (m, 14H), $3.43(\mathrm{t}, 1 \mathrm{H}), 2.92$ $(\mathrm{t}, 1 \mathrm{H}), 2.68-2.47(\mathrm{~m}, 4 \mathrm{H}), 2.30(\mathrm{~s}, 3 \mathrm{H}), 2.23(\mathrm{~s}, 3 \mathrm{H}) ;{ }^{13} \mathrm{C}$ NMR (400 MHz, DMSO- $\left.d_{6}\right): \delta(\mathrm{ppm})$ 102.1-101.6 (m), 84.2, 81.6-81.1 (m), 73.2-71.9 (m), 70.2, 59.8, 58.3, 56.9, 48.8, 42.7, 35.7, 29.2; MS (ESI): $m / z 1207\left[M+\mathrm{H}_{2}\right]^{+}, 1206[M+\mathrm{H}]^{+}$.

CD-6: yield 46.6\%; $[\alpha]_{\mathrm{D}}^{25}+149.87\left(c 0.2105, \mathrm{H}_{2} \mathrm{O}\right) ; \mathrm{mp}>240$ ${ }^{\circ} \mathrm{C}$ (decomp.); ${ }^{1 \mathrm{H}}$ NMR (400 MHz, $\mathrm{D}_{2} \mathrm{O}$ ): $\delta$ (ppm) 5.13-5.03 (m, 7H), 4.01-3.79 (m, 26H), 3.70-3.53 (m, 14H), 3.60-3.38 (m, 1H), 3.15-2.95 (m, 2H), 2.89-2.42 (m, 4H), $1.07(\mathrm{~d}, 3 \mathrm{H}) ;{ }^{13} \mathrm{C}$ NMR (400 MHz, DMSO- $d_{6}$ ): $\delta$ (ppm) 101.7-101.4 (m), 83.1, 81.1, 72.6-71.6 (m), 70.4-69.7 (m), 59.5, 57.1, 57.0, 54.2, 54.0, 49.2-49.1 (m) , 46.8, 46.4, 45.8, 45.6, 20.85, 17.8, 17.6; MS (ESI): $m / z 1193\left[M+\mathrm{H}_{2}\right]^{+}, 1192[M+\mathrm{H}]^{+}$.

CD-7: yield 30.1\%; $[\alpha]_{\mathrm{D}}^{25}+146.52\left(c 0.2081, \mathrm{H}_{2} \mathrm{O}\right) ; \mathrm{mp}>240$ ${ }^{\circ} \mathrm{C}$ (decomp.); ${ }^{1 \mathrm{H}}$ NMR (400 MHz, $\mathrm{D}_{2} \mathrm{O}$ ): $\delta$ (ppm) 5.07-4.97 (m, 7H), 3.98-3.76 (m, 26H), 3.62-3.50 (m, 14H), 3.43 (t, 1H), 2.92 (d, 1H), 2.64-2.38 (m, 4H), $2.40(\mathrm{~s}, 3 \mathrm{H}), 2.22$ (s, 3H), 1.65-1.58 $(\mathrm{m}, 2 \mathrm{H}) ;{ }^{13} \mathrm{C}$ NMR (400 MHz, DMSO- $\left.d_{6}\right): \delta$ (ppm) 102.2-101.5 (m), 84.1, 81.5-81.1 (m), 79.1, 73.2-71.8 (m), 70.2, 59.9-59.6(m), 58.0, 56.2, 49.6, 42.9, 35.8, 26.6; MS (ESI): $m / z$ $1221\left[M+\mathrm{H}_{2}\right]^{+}, 1220[M+\mathrm{H}]^{+}$.

CD-8: yield 50.6\%; $[\alpha]_{\mathrm{D}}^{25}+156.72\left(c 0.2064, \mathrm{H}_{2} \mathrm{O}\right) ; \mathrm{mp}>240$ ${ }^{\circ} \mathrm{C}$ (decomp.); ${ }^{1} \mathrm{H}$ NMR (400 MHz, $\left.\mathrm{D}_{2} \mathrm{O}\right): \delta$ (ppm) 5.01-4.92 (m, $7 \mathrm{H}), 3.88-3.74(\mathrm{~m}, 26 \mathrm{H}), 3.56-3.45(\mathrm{~m}, 14 \mathrm{H}), 3.32(\mathrm{t}, 1 \mathrm{H}), 2.94$ (d, $1 \mathrm{H}), 2.70-2.49(\mathrm{~m}, 5 \mathrm{H}), 1.58-1.51(\mathrm{~m}, 2 \mathrm{H}) ;{ }^{13} \mathrm{C}$ NMR $(400$ MHz, DMSO-d6): $\delta$ (ppm) 101.8, 101.4, 83.6, 81.1, 80.8, 73.0-72.9 (m), 72.0-71.7 (m), 70.3, 60.2-60.1 (m), 49.4, 46.4, 38.5, 37.9, 32.5, 30.8; MS (ESI): $m / z 1193\left[M+\mathrm{H}_{2}\right]^{+}, 1192[M+$ $\mathrm{H}]^{+}$.

CD-9: yield 52.4\%; $[\alpha]_{\mathrm{D}}^{25}+148.15\left(c 0.2036, \mathrm{H}_{2} \mathrm{O}\right) ; \mathrm{mp}>240$ ${ }^{\circ} \mathrm{C}$ (decomp.); ${ }^{1} \mathrm{H}$ NMR (400 MHz, $\left.\mathrm{D}_{2} \mathrm{O}\right): \delta$ (ppm) 5.02-5.00 (m, $7 \mathrm{H}), 3.93-3.79(\mathrm{~m}, 26 \mathrm{H}), 3.60-3.49(\mathrm{~m}, 14 \mathrm{H}), 3.38(\mathrm{t}, 1 \mathrm{H})$, $3.01-2.98(\mathrm{~m}, 1 \mathrm{H}), 2.77-2.58(\mathrm{~m}, 7 \mathrm{H}){ }^{13} \mathrm{C} \mathrm{NMR}\left(400 \mathrm{MHz}, \mathrm{D}_{2} \mathrm{O}\right)$ : $\delta(\mathrm{ppm})$ 101.8, 100.5, 83.6, 81.1, 80.9, 73.1-73.0 (m), 72.0-72.0 (m), 71.8, 70.4, 60.2, 50.7, 49.3, 42.2, 39.7; MS (ESI): $m / z 1178$
$\left[M+\mathrm{H}_{2}\right]^{+}, 1177[M+\mathrm{H}]^{+}$.

\subsection{Typical procedure for asymmetric Michael reaction}

Aqueous $\mathrm{CH}_{3} \mathrm{COONa}-\mathrm{HCl}$ buffer solution ( $1 \mathrm{~mL}, 0.5 \mathrm{~mol} / \mathrm{L}$ ) and cyclohexanone $(0.2 \mathrm{~mL}, 2 \mathrm{mmol})$ were added to a stirred solution of CD-1 ( $0.0487 \mathrm{~g}, 0.04 \mathrm{mmol})$ and 4-nitro- $\beta$-nitrostyrene $(0.0388 \mathrm{~g}, 0.20 \mathrm{mmol})$. The solution was stirred at $25{ }^{\circ} \mathrm{C}$ for $96.0 \mathrm{~h}$ and then extracted with ethyl acetate $(3 \times 2 \mathrm{~mL})$. The combined organic phases were dried over anhydrous $\mathrm{Na}_{2} \mathrm{SO}_{4}$ and the solvent was evaporated under reduced pressure to give the crude product, which was purified by column chromatography over silica gel. The yield and ee were determined using HPLC.

\subsection{Preparation of $C D-1$ inclusion complex of 4-nitro- $\beta$-nitrostyrene}

A mixture of CD-1 (0.6085 g, $0.5 \mathrm{mmol})$ and 4-nitro- $\beta$-nitrostyrene $(0.0970 \mathrm{~g}, 0.5 \mathrm{mmol})$ in deionized water $(10 \mathrm{~mL})$ was stirred at $50{ }^{\circ} \mathrm{C}$ for $2 \mathrm{~h}$, i.e., until the solution was clear. The solution was cooled at $5{ }^{\circ} \mathrm{C}$ for $24 \mathrm{~h}$ and filtered to give a light yellow precipitate. The precipitate was washed with hexane to remove free 4-nitro- $\beta$-nitrostyrene. The inclusion complex was dried under vacuum at $50{ }^{\circ} \mathrm{C}$ for $24 \mathrm{~h}$.

\subsection{Quantum chemical calculations}

Quantum chemical calculations were performed using the GAUSSIAN 09 program to investigate the energies and structures of CD-1 and 4-nitro- $\beta$-nitrostyrene. The initial $\beta$-CD structure was constructed using information available in Ref. [26]. The modifying amino groups and the guest molecule 4-nitro- $\beta$-nitrostyrene were constructed using ChemBioOffice 3D Ultra (Version 12.0, Cambridge Software) and were fully optimized using the PM3 and B3LYP/6-31G(d) methods, without any symmetric restrictions. The optimized amino groups were attached to $C-6$ of $\beta$-CD and the modified $\beta$-CDs were optimized using PM3. In the coordinate system, the glycosidic oxygen atoms of $\beta$-CD were placed in the $X Y$ plane and their center was defined as the origin. The $\mathrm{C}-2$ and $\mathrm{C}-3$ hydroxyls were placed on the negative $Z$ axis. The guest molecule, i.e., 4 -nitro- $\beta$-nitrostyrene, was located with three virtual atoms in the coordinates, two in the $X Y$ plane, and one on the $Z$ axis. The carbon atom linked to the nitro group in the benzene ring of 4 -nitro- $\beta$-nitrostyrene was the labeled atom. The inclusion complexes were optimized based on the PM3 calculation to obtain the optimized energies, and the output files were used as the input files for optimization at the ONIOM level (B3LYP/6-31G(d):PM3). The binding energy (BE) was calculated as $\mathrm{BE}=E[\mathrm{C}]_{\text {ONIOM }}-E[\mathrm{H}]_{\mathrm{PM} 3}-E[\mathrm{G}]_{\mathrm{B} 3 \mathrm{LYP} / 6-31 \mathrm{G}(\mathrm{d}) \text {, where }}$ $E[C]_{\text {oniom }}$ is the optimized energy of the inclusion complex obtained using the ONIOM (B3LYP/6-31G(d):PM3) method, $E[\mathrm{H}]_{\mathrm{PM} 3}$ is the optimized energy of the modified CD obtained using PM3, and $E[\mathrm{G}]_{\mathrm{B} 3 \mathrm{LYP} / 6-31 \mathrm{G}(\mathrm{d})}$ is the optimized energy of the guest molecule, i.e., 4-nitro- $\beta$-nitrostyrene, obtained using B3LYP/6-31G(d). 


\section{Results and discussion}

\subsection{Optimization of asymmetric Michael addition conditions}

The diamine-catalyzed Michael addition is $\mathrm{p} K_{\mathrm{a}}$ dependent; therefore, the effect of $\mathrm{pH}$ on the enantioselectivity of the asymmetric Michael addition catalyzed by CD- 1 was studied in detail. The effect of $\mathrm{pH}$ on the catalytic activity and enantioselectivity in the asymmetric Michael addition catalyzed by CD-1, assuming an intermolecular enamine transition state, is shown in Table 1. When the $\mathrm{pH}$ of the $\mathrm{CH}_{3} \mathrm{COONa}-\mathrm{HCl}$ buffer solution was kept at 6.0 or lower, both the amino group in the pyrrolidine and the secondary amine linked to C-6 were protonated, therefore the active catalytic center became inactive (Table 1 , entries 1-5), and no catalytic activity was observed. When the $\mathrm{pH}$ was increased from 6.5 to 7.5 , the ee increased from $42 \%$ (Table 1, entry 6) to $61 \%$ (Table 1 , entry 8 ), and the yield increased from $13 \%$ to $46 \%$, because protonation of the secondary amine became weaker, and both amino groups were able to catalyze the Michael addition with moderate enantioselectivity and yield.

When CD-1 dosage was decreased to half, the yield was halved (Table 1, entry 10), but the ee remained almost the same. This shows that in water the effect of the $\mathrm{pH}$ on the enantioselectivity was greater than that of the catalyst dosage. There is an optimum $\mathrm{p} K_{\mathrm{a}}$ for the amines to be effective, which in the present case was 7.5.

\subsection{Asymmetric Michael additions with various modified $\beta$-CDs}

On the basis of the initial experiments, the reactions using

Table 1

Effect of $\mathrm{pH}$ on enantioselectivity in asymmetric Michael reactions catalyzed by CD-1.

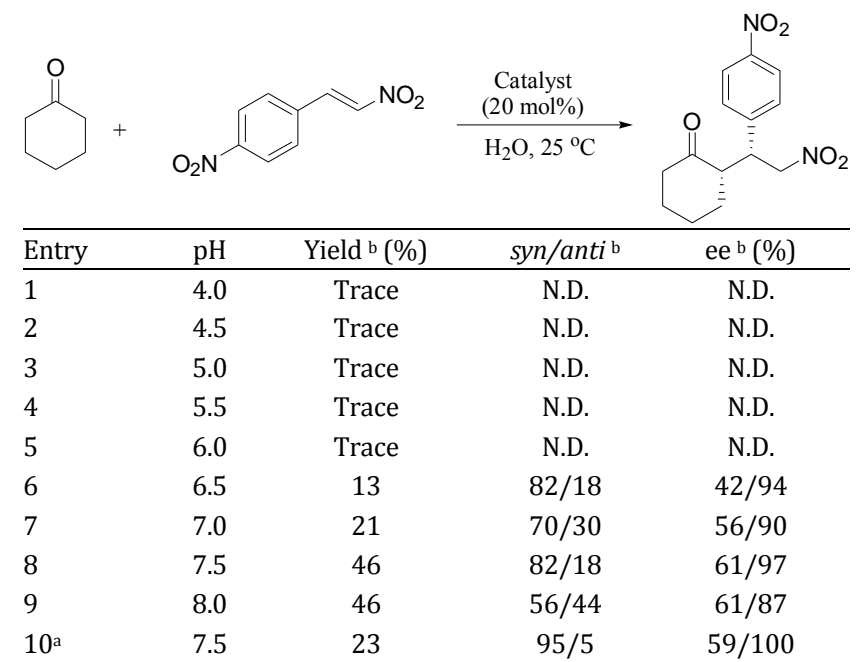

Reaction conditions: CD-1 $0.04 \mathrm{mmol}$, 4-nitro- $\beta$-nitrostyrene $0.20 \mathrm{mmol}$, cyclohexanone $2 \mathrm{mmol}$, solvent ( $\left.0.5 \mathrm{~mol} / \mathrm{L} \mathrm{CH}_{3} \mathrm{COONa}-\mathrm{HCl}\right) 2 \mathrm{~mL}, 25^{\circ} \mathrm{C}$, $96.0 \mathrm{~h}$.

${ }^{a}$ CD-1 0.02 mmol. b Determined by HPLC analysis with a Chiralcel OD-H column. The absolute configurations of the Michael addition products were determined by comparison of the eluting sequence of the enantiomers with the authentic sample and Ref. [27].

N.D.: Not determined.
Table 2

Effect of modifying group structure on enantioselectivity in asymmetric Michael reactions.

\begin{tabular}{lcccc}
\hline Entry & CDs & Yield $^{\text {a }}(\%)$ & syn/anti & ee $^{\text {a }}(\%)$ \\
\hline 1 & CD-1 & 46 & $82 / 18$ & $61 / 97$ \\
2 & CD-2 & 17 & $76 / 24$ & $41 / 93$ \\
3 & CD-3 & 7.5 & $99 / 1$ & $34 / 37$ \\
4 & CD-4 & 6.2 & $81 / 19$ & $16 / 63$ \\
5 & CD-5 & 6.1 & $71 / 29$ & $5 / 77$ \\
6 & CD-6 & 44 & $77 / 23$ & $1 / 96$ \\
7 & CD-7 & 33 & $73 / 27$ & $4 / 100$ \\
8 & CD-8 & 49 & $74 / 26$ & $4 / 98$ \\
9 & CD-9 & 96 & $87 / 13$ & $1 / 98$ \\
\hline
\end{tabular}

Reaction conditions: modified CDs $0.04 \mathrm{mmol}$, 4-nitro- $\beta$-nitrostyrene $0.20 \mathrm{mmol}$, cyclohexanone $2 \mathrm{mmol}$, solvent $(\mathrm{pH} 7.5,0.5 \mathrm{~mol} / \mathrm{L}$ $\left.\mathrm{CH}_{3} \mathrm{COONa}-\mathrm{HCl}\right) 2 \mathrm{~mL}, 25^{\circ} \mathrm{C}, 96.0 \mathrm{~h}$.

a Determined by HPLC analysis with a Chiralcel OD-H column. The absolute configurations of the Michael products were determined by comparison of the eluting sequence of the enantiomers with the authentic sample and Ref. [27].

$\beta$-CDs modified with various diamines were investigated at $\mathrm{pH}$ 7.5; the results are shown in Table 2. The CD-9-catalyzed Michael addition gave a good yield $96 \%$ (Table 2, entry 9) but poor ee. The enantioselectivity did not improve when the ethylenediamine group in CD-9 was substituted with one methyl group (CD-6) or two methyl groups (CD-5), and the reaction yields decreased to $44 \%$ (Table 2, entry 6) and 6\% (Table 2, entry 5), respectively. The same substituent effect was observed with the 1,3-propanediamine-based catalysts CD-8 and CD-7; the reaction yield decreased from $49 \%$ (Table 2, entry 8 ) to $33 \%$ (Table 2, entry 7). Catalysts containing a tertiary amino group, i.e., CD-4 and CD-5, and a bifunctional secondary amine, i.e., CD-3, were inert and gave low yields. These 6-monosubsituted $\beta$-CD derivatives would mainly exist in self-included conformations in pure water solutions, as shown by previous studies, therefore the reaction rates decreased [20]. The difference between CD-1 and CD- 2 was the absolute configuration of the appended modifying group; CD-1 showed better catalytic efficiency and enantioselectivity ( $61 \%$ ee vs $41 \%$ ee) than did CD-2. Quantum chemical calculations showed that their optimum conformations were different [25], because the secondary amine in the pyrrolidine ring cannot be included in the hydrophobic cavity of CD-2, giving racemic products. The structure and absolute configuration of the modifying group in the $\beta$-CD therefore plays a decisive role in the catalytic activity and in inducing enantioselectivity in the asymmetric Michael addition.

The enantioselectivity of conjugate addition in amine organocatalysis is induced and controlled through three routes, i.e., (1) formation of an enamine or imine; (2) non-covalent interactions such as hydrogen bonding; and (3) steric hindrance. Catalysis using the modified $\beta$-CDs CD- 1 to CD-9 could therefore be improved by considering these factors.

\subsection{CD-1-catalyzed asymmetric Michael additions of various substrates}

The CD-1-catalyzed asymmetric Michael additions of cyclohexanone to a variety of conjugated nitroolefins were investi- 
Table 3

CD-1-catalyzed asymmetric Michael reactions of various substrates.

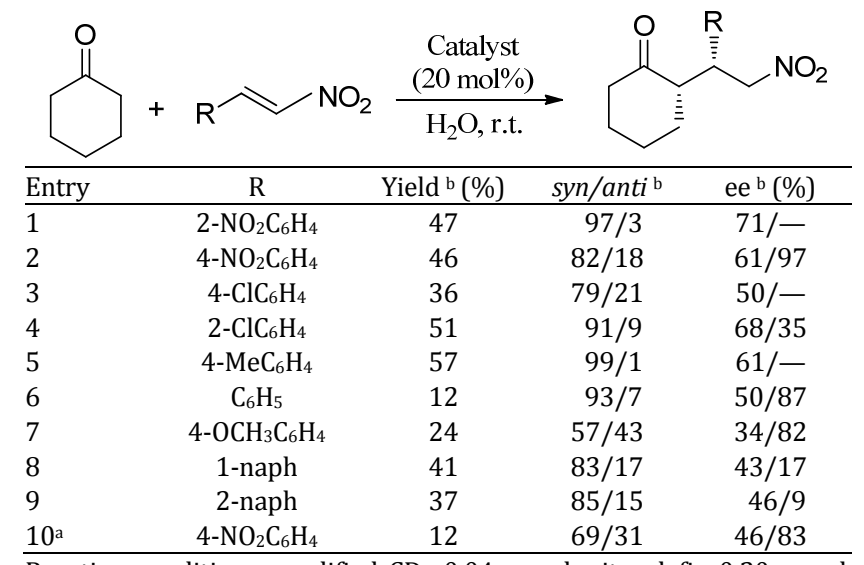

Reaction conditions: modified CDs $0.04 \mathrm{mmol}$, nitroolefin $0.20 \mathrm{mmol}$, cyclohexanone $2 \mathrm{mmol}$, solvent (pH 7.5, $\left.0.5 \mathrm{~mol} / \mathrm{L} \mathrm{CH}_{3} \mathrm{COONa}-\mathrm{HCl}\right) 2$ $\mathrm{mL}, 25^{\circ} \mathrm{C}, 96.0 \mathrm{~h}$.

a 2-Adamantanone $0.04 \mathrm{mmol}$ was added.

b Determined by HPLC analysis with a Chiralcel AS-H column and a Chiralcel OD-H column. The absolute configurations of the Michael products were determined by comparison of the eluting sequence of the enantiomers with the authentic sample and Refs. [27-29].

gated. Additions of cyclohexanone to substituted nitroolefins containing both electron-withdrawing and electron-donating groups were studied; the results are shown in Table 3. In most cases, the corresponding Michael adducts were obtained with moderate diastereoselectivity and enantioselectivity, suggesting that electronic factors slightly influenced the enantioselectivity. The highest ee, i.e., 71\%, was obtained with 2 -nitro- $\beta$ nitrostyrene (Table 3 , entry 1 ); the value for 4 -nitro- $\beta$-nitrostyrene was $61 \%$ (Table 3, entry 2). The observed enantioselectivity can be rationalized based on quantum chemical calculations. The side views of the optimized geometries of the inclusion complexes between the two substrates and CD-1 were visualized, as shown in Fig. 1. The active site of the double bond in 4-nitro- $\beta$-nitrostyrene was deep inside the cavity of CD-1 (Fig. 1(b)), but the active site of 2-nitro- $\beta$-nitrostyrene remained outside the narrow rim of CD-1 (Fig. 1(a)); this is attributed to the ortho substituent making the binary complex more crowded. Steric hindrance might therefore improve enantioselection and give higher ee values. The same ortho sub-

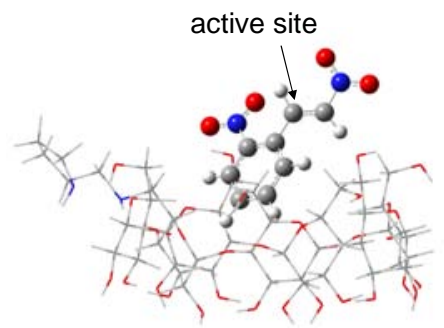

(a)

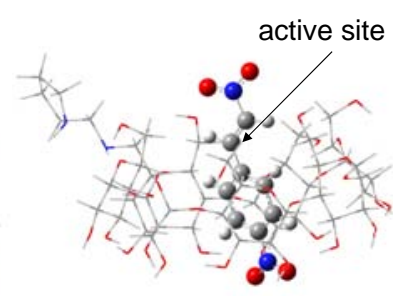

(b)

$$
\Delta E=-644.05 \mathrm{~kJ} / \mathrm{mol}
$$$$
\Delta E=-648.31 \mathrm{~kJ} / \mathrm{mol}
$$

Fig. 1. Side views of optimized geometries of inclusion complexes between CD-1 and 2-nitro- $\beta$-nitrostyrene (a) and 4-nitro- $\beta$-nitrostyrene (b), obtained at ONIOM level (B3LYP/6-31G(d):PM3). stituent effect was observed in the cases of Table 3, entry 3 (50\% ee) and entry 4 (68\% ee).

The yield and optical yield decreased from $46 \%$ and $61 \%$ (Table 3, entry 2) to $12 \%$ and $46 \%$ (Table 3, entry 10 ), respectively, when 2 -adamantanone $(0.2$ equiv. relative to 4 -nitro- $\beta$ nitrostyrene) was added to the reaction system. 2-Adamantanone immediately forms a 1:1 inclusion complex with $\beta$-CD and can be used as a competitive inhibitor in the formation of inclusion complex, resulting in inhibition of the catalytic process, i.e., the hydrophobic cavity is necessary in the present asymmetric Michael addition.

\subsection{Mechanistic studies}

$\beta$-CD can form inclusion complexes with guest molecules, and the formation of inclusion complexes is important in the induction of enantioselectivity. In this study, inclusion complexes between modified $\beta$-CDs and 4-nitro- $\beta$-nitrostyrene were prepared by stirring mixtures of CD-1 to CD-9 and 4 -nitro- $\beta$-nitrostyrene in water; the complexes were characterized using ${ }^{1} \mathrm{H}$ rotating-frame overhauser effect spectroscopy (ROESY), UV spectroscopy, and quantum chemical calculations. The ${ }^{1} \mathrm{H}$ ROESY results for the inclusion complex between CD-1 and 4-nitro- $\beta$-nitrostyrene is shown as an example in Fig. 2. The clear correlation peaks between the $\mathrm{H}$ atoms located in the phenyl ring of 4-nitro- $\beta$-nitrostyrene and $\mathrm{H}-3$ and $\mathrm{H}-5$ in the cavity of the parent $\beta$-CD indicate formation of an inclusion complex between CD-1 and 4-nitro- $\beta$-nitrostyrene. No correlation peaks between the $\mathrm{H}$ atoms located in the phenyl ring of 4-nitro- $\beta$-nitrostyrene and $\mathrm{H}-2$ and $\mathrm{H}-4$ outside the parent $\beta$-CD are observed. These results show that in the inclusion complex of CD-1 and 4-nitro- $\beta$-nitrostyrene, the phenyl ring is almost entirely situated in the cavity of the parent $\beta$-CD.

Fig. 3 shows that the UV absorbance changed when 4 -nitro- $\beta$-nitrostyrene was treated with solutions of the $C D$ catalysts; for example, the absorbance decreased when CD-1 was added to a dilute solution of 4-nitro- $\beta$-nitrostyrene in water and DMF, suggesting formation of a complex between CD-1 and 4-nitro- $\beta$-nitrostyrene.

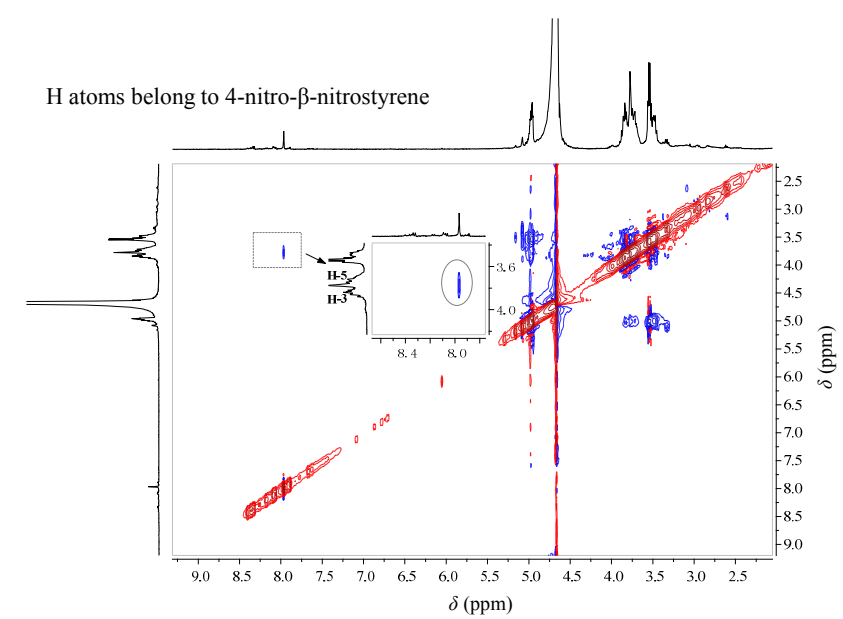

Fig. 2. ${ }^{1} \mathrm{H}$ ROESY results for CD-1 and 4-nitro- $\beta$-nitrostyrene in $\mathrm{D}_{2} \mathrm{O}$ at $25^{\circ} \mathrm{C}$. 


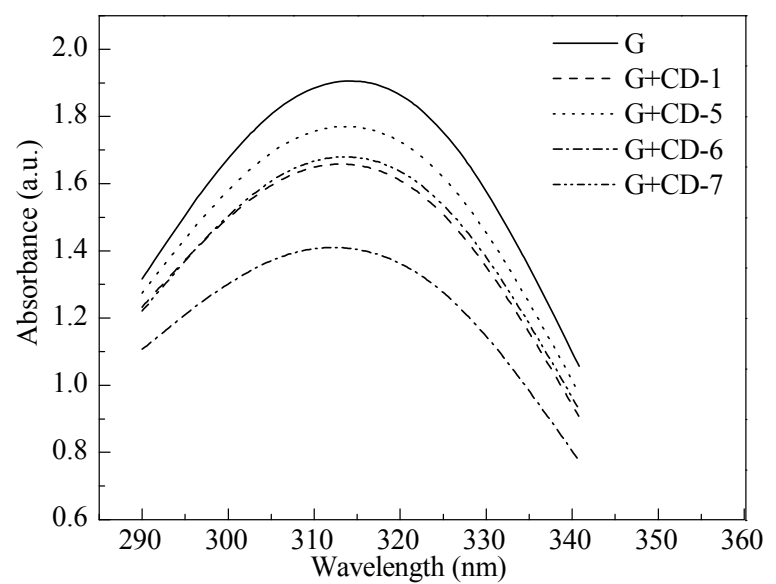

Fig. 3. Effect of $\beta$-CD derivatives CD-1, and CD-5 to CD-7 on UV absorbance of 4-nitro- $\beta$-nitrostyrene. G: 4-nitro- $\beta$-nitrostyrene $0.10 \mathrm{mmol} / \mathrm{L}$; $\beta$-CD derivatives $0.10 \mathrm{mmol} / \mathrm{L}$; solvent DMF/water $3 / 1(\mathrm{v} / \mathrm{v}), 20^{\circ} \mathrm{C}$.

The inclusion complex was investigated in greater detail by determining the BEs of the inclusion complexes between the modified $\beta$-CDs and 4-nitro- $\beta$-nitrostyrene using quantum chemical calculations at the ONIOM (B3LYP/6-31G(d):PM3) level to verify the intramolecular interactions (Table 4). The negative BE indicates that formation of an inclusion complex is thermodynamically favorable and spontaneous; two models of the inclusion complex are shown in Fig. 4. In model (a), the catalytic center is next to the active site and intramolecular catalysis would occur, giving a chiral product. In model (b), the catalytic center is beyond the active site and intermolecular catalysis would occur, giving an achiral product. However, the difference between the BEs for models (a) and (b) is just below $15 \mathrm{~kJ} / \mathrm{mol}$, a low energy barrier, for each modified $\beta$-CD. The difference between the BEs of models (a) and (b) can therefore be ignored, and both are involved in the asymmetric Michael addition. When intramolecular catalysis is dominant, a better ee is achieved. The probabilities of Michael addition of $\beta$-nitrostyrene to cyclohexanone are nearly the same for models (a) and (b), and a moderate enantioselectivity (50\% ee, Table 3 , entry 6) was achieved. Increased steric hindrance of the nitroolefin increased the enantioselectivity to some extent.

These results suggest that the mechanism of Michael addition is similar to that suggested by $\mathrm{Xu}$ and co-workers [30].

Table 4

Binding energies (BEs) of CD-1 to CD-9 with 4-nitro- $\beta$-nitrostyrene in two models.

\begin{tabular}{lcccc}
\hline Entry & $\mathrm{CDs}$ & $\mathrm{BE}_{\mathrm{a}}(\mathrm{kJ} / \mathrm{mol})$ & $\mathrm{BE}_{\mathrm{b}}(\mathrm{kJ} / \mathrm{mol})$ & $\Delta \mathrm{BE}^{\mathrm{a}}(\mathrm{kJ} / \mathrm{mol})$ \\
\hline 1 & $\mathrm{CD}-1$ & -648.31 & -649.86 & 1.55 \\
2 & $\mathrm{CD}-2$ & -649.97 & -641.83 & -8.14 \\
3 & $\mathrm{CD}-3$ & -649.86 & -651.46 & 1.60 \\
4 & $\mathrm{CD}-4$ & -647.68 & -652.07 & 4.39 \\
5 & $\mathrm{CD}-5$ & -650.60 & -650.72 & 0.12 \\
6 & $\mathrm{CD}-6$ & -658.66 & -643.85 & -14.81 \\
7 & $\mathrm{CD}-7$ & -652.19 & -648.70 & -3.49 \\
8 & $\mathrm{CD}-8$ & -648.18 & -645.08 & -3.10 \\
9 & $\mathrm{CD}-9$ & -649.50 & -651.51 & 2.01 \\
\hline
\end{tabular}

All calculations were carried out by using the GAUSSIAN 03 program at the level of ONIOM(B3LYP/6-31G(d): PM3).

a $\triangle \mathrm{BE}=\mathrm{BE}_{\mathrm{a}}-\mathrm{BE}_{\mathrm{b}}$.

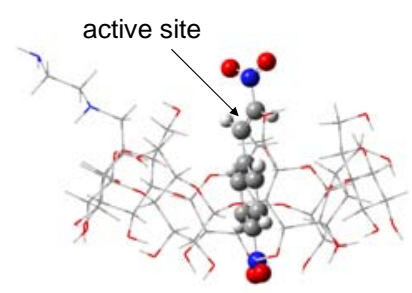

(a)

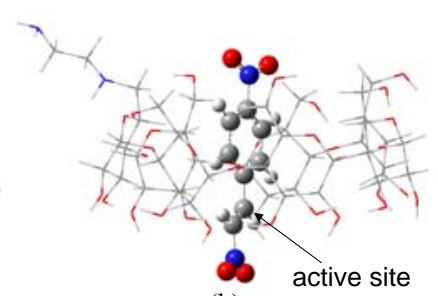

(b)
Fig. 4. Two proposed models of binding between CD-9 and 4-nitro- $\beta$-nitrostyrene.

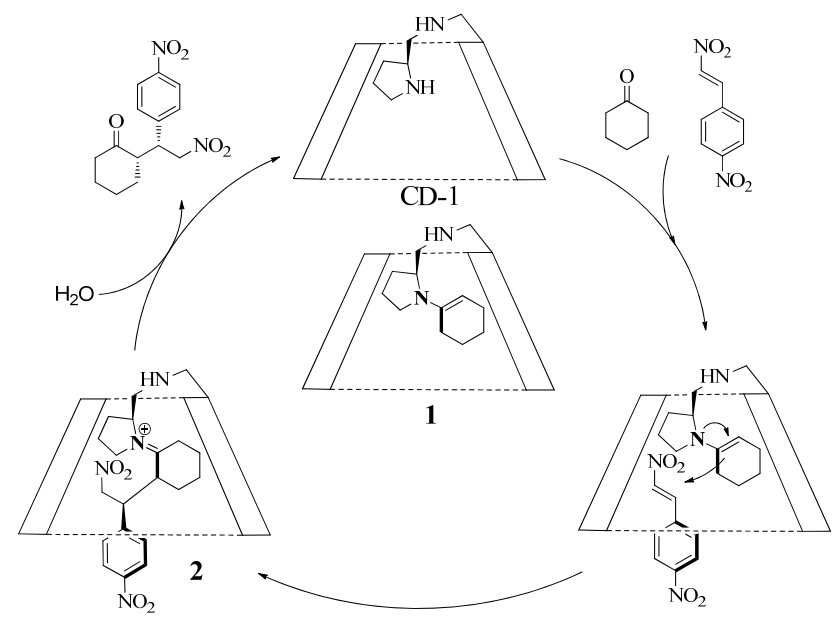

Scheme 3. Suggested mechanism of asymmetric Michael addition catalyzed by CD-1.

When primary or secondary chiral amines are used as organocatalysts, the reaction proceeds via an enamine pathway. A plausible mechanism is as follows (Scheme 3). The initial step is formation of a chiral enamine $\mathbf{1}$ between CD-1 and cyclohexanone. Michael addition, the $\mathrm{C}-\mathrm{C}$ bond-forming step, between $\mathbf{1}$ and 4-nitro- $\beta$-nitrostyrene occurs, leading to formation of the corresponding product via transition state 2 . The product is released and escapes from the cavity and CD- 1 is regenerated for use in subsequent catalytic cycles.

\section{Conclusions}

Nine $\beta$-CD derivatives containing amino-groups were used in asymmetric Michael additions in water. The (S)-2-aminomethylpyrrolidine-modified $\beta$-CD (CD-1) gave the best performance, with $71 \%$ ee being obtained. The structure of the modifying group, $\mathrm{pH}$, and steric hindrance between the substrate and the modified $\beta$-CD played important roles in inducing enantioselectivity in the asymmetric Michael addition. Quantum chemical calculations were effective in investigating the enantioselectivities of Michael additions using various $\beta-C D$ derivatives. Studies of the use of CD-1 in other asymmetric reactions are in progress.

\section{References}

[1] S. B. Tsogoeva, Eur. J. Org. Chem., 2007, 1701-1716.

[2] B. M. Trost, J. Hitce, J. Am. Chem. Soc., 2009, 131, 4572-4573.

[3] D. W. C. MacMillan, Nature, 2008, 455, 304-308. 


\title{
Graphical Abstract
}

Chin. J. Catal., 2016, 37: 1227-1234 doi: 10.1016/S1872-2067(15)61122-6

Biomimetic asymmetric Michael addition reactions in water catalyzed by amino-containing $\beta$-cyclodextrin derivatives

Qingying Zhu, Haimin Shen, Zhujin Yang, Hongbing Ji * Sun Yat-sen University; Zhejiang University of Technology

(S)-2-Aminomethylpyrrolidine-modified $\beta$-cyclodextrins were synthesized and used in asymmetric Michael additions of cyclohexanone and 4-nitro- $\beta$-nitrostyrene in water at room temperature. Moderate yields and higher enantioselectivity for the syn addition product were obtained.

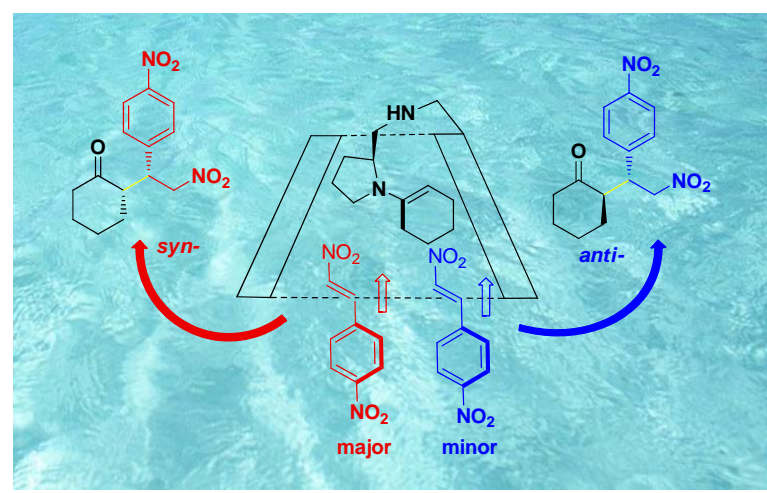

[4] K. Liu, H. F. Cui, J. Nie, K. Y. Dong, X. J. Li, J. A. Ma, Org. Lett., 2007, 9, 923-925.

[5] S. E. Syu, T. T. Kao, W. W. Lin, Tetrahedron, 2010, 66, 891-897.

[6] H. C. Huang, K. L. Zhu, W. B. Wu, Z. C. Jin, J. X. Ye, Chem. Commun., 2012, 48, 461-463.

[7] Z. Dong, G. Qiu, H. B. Zhou, C. Dong, Tetrahedron Asymmetry, 2012, $23,1550-1556$.

[8] Y. N. Belokon, Z. T. Gugkaeva, V. I. Maleev, M. A. Moskalenko, A. T. Tsaloev, V. N. Khrustalev, K. V. Hakobyan, Tetrahedron Asymmetry, 2011, 22, 167-172.

[9] H. Y. Bae, S. Some, J. S. Oh, Y. S. Lee, C. E. Song, Chem. Commun., 2011, 47, 9621-9623.

[10] F. R. Zhong, X. W. Dou, X. Y. Han, W. J. Yao, Q. Zhu, Y. Z. Meng, Y. X. Lu, Angew. Chem. Int. Ed., 2013, 52, 943-947.

[11] D. Z. Xu, Y. J. Liu, S. Shi, Y. M. Wang, Tetrahedron Asymmetry, 2010, 21, 2530-2534.

[12] K. Akagawa, K. Kudo, Angew. Chem. Int. Ed., 2012, 51, 12786-12789.

[13] S. Sukumari, I. A. Azath, K. Pitchumani, Synlett, 2012, 2328-2332.

[14] M. E. Deary, D. M. Davies, Carbohydrate Res., 1999, 317, 10-18.

[15] Z. J. Yang, H. B. Ji, Chin. J. Catal., 2014, 35, 590-598.

[16] R. Breslow, S. D. Dong, Chem. Rev., 1998, 98, 1997-2011.

[17] A. Schlatter, W. D. Woggon, Adv. Synth. Catal., 2008, 350,

995-1000.

[18] H. M. Shen, H. B. Ji, Carbohydrate Res., 2012, 354, 49-58.

[19] T. H. Fenger, L.G. Marinescu, M. Bols, Eur. J. Org. Chem., 2011, 2339-2345.

[20] S. S. Hu, J. Y. Li, J. F. Xiang, J. Pan, S. Z. Luo, J. P. Cheng, J. Am. Chem. Soc., 2010, 132, 7216-7228.

[21] K. Kanagaraj, P. Suresh, K. Pitchumani, Org. Lett., 2010, 12, 4070-4073.

[22] I. Tabushi, Y. Kuroda, M. Yamada, H. Higashimura, J. Am. Chem. Soc., 1985, 107, 5545-5546.

[23] P. Suresh, K. Pitchumani, Tetrahedron Asymmetry, 2008, 19, 2037-2044.

[24] H. Sakuraba, Y. Tananaka, F. Toda, J. Incl. Phenom. Mol. Recog. Chem., 1991, 11, 195-204.

[25] H. M. Shen, H. B. Ji, Tetrahedron Lett., 2012, 53, 3541-3545.

[26] C. Betzel, W. Saenger, B. E. Hingerty, G. M. Brown, J. Am. Chem. Soc., 1984, 106, 7545-7557.

[27] J. R. Chen, L. Fu, Y. Q. Zou, N. J. Chang, J. Rong, W. J. Xiao, Org. Biomol. Chem., 2011, 9, 5280-5287.

[28] J. N. Moorthy, S. Saha, Eur. J. Org. Chem., 2010, 6359-6365.

[29] S. Z. Luo, X. L. Mi, L. Zhang, S. Liu, H. Xu, J. P. Cheng, Angew. Chem. Int. Ed., 2006, 45, 3093-3097.

[30] D. Z. Xu, S. Shi, Y. M. Wang, Eur. J. Org. Chem., 2009, 4848-4853.

\section{氨基修饰 $\beta$-环糊精衍生物水相仿生催化不对称 Michael 加成反应}

\author{
朱庆英 ${ }^{\mathrm{a}}$, 沈海民 ${ }^{\mathrm{b}}$, 杨祖金 ${ }^{\mathrm{a}}$, 纪红兵 ${ }^{\mathrm{a},{ }^{*}}$ \\ a中山大学化学与化学工程学院化工系, 广东广州 510275

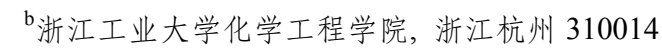

摘要: 在不对称 Michael 加成反应中, 有机小分子如伯胺、吡咯烷类衍生物、(硫) 腿类、手性方酰胺、联䒺类、奎宁类、 手性膦、离子液体和肽类等是目前使用的主要催化剂, 如果能避免或少量使用有机溶剂, 则更符合 “绿色化学” 的环境友 好发展方向. $\beta$-环糊精的内腔疏水, 而外部亲水, 可以类似酶分子结合有机反应物, 在水相体系进行催化反应. 当 $\beta$-环糊精 分子上连接催化部位或结合部位时, 能产生更优异的包结底物和诱导对映选择性的能力. 目前基于 $\beta$-环糊精衍生物构筑人 工类酶催化剂用于不对称 Michael 加成反应的报道较少. 本文通过亲核取代反应将氨基类有机小分子与单 (6- $O-p$-甲苯磺 酰基)- $\beta$-环糊精结合, 得到 9 个氨基修饰 $\beta$-环糊精衍生物 CD-1-CD-9 (收率在 24.2\%-64.9\%, 分子结构通过 ${ }^{1} \mathrm{H}$ NMR, ${ }^{13} \mathrm{C}$ NMR 和 ESI-MS 表征确认), 并用于室温水相体系不对称 Michael 加成的仿生催化反应, 以期获得较好的催化反应活性和对 映选择性.

通过设计不同 $\beta$-环糊精衍生物的修饰基团结构、改变反应介质 $\mathrm{pH}$ 值和反应底物结构,分析了 Michael 加成反应体系产 
物产率和对映选择性的变化, 采用 $2 \mathrm{D}-{ }^{1} \mathrm{H}$ ROESY NMR、紫外吸收光谱、红外光谱和和量子化学计算, 分析了 $\beta$-环糊精衍生 物和反应底物分子的包结状态, 探究了反应过程机理. 结果显示, 在该水相体系中进行的不对称 Michael 加成反应产物产率 和对映体过量值 (ee 值) 受修饰基团结构、反应介质 $\mathrm{pH}$ 值和底物结构影响较大. 当反应介质 $\mathrm{pH}$ 值低于 6.0 时, 由于氨基分 子被质子化而失去催化活性; 当 $\mathrm{pH}$ 值为 7.5 时, 获得中等水平的对映选择性，通过量子化学在 ONIOM (B3LYP/6-31G(d):PM3)水平上的优化计算发现, 底物分子与 $\beta$-环糊精衍生物的包结可以出现两种形式: 当底物分子的活性 部位接近 $\beta$-环糊精衍生物小口端的修饰基团时, 产生分子内催化, 诱导反应产生较好的对映选择性; 当底物分子的活性部位 远离 $\beta$-环糊精衍生物小口端的修饰基团时, 产生分子间催化, 几乎没有对映选择性, 而这两种情况同时存在. 当底物分子以 较大的空间位阻与 $\beta$-环糊精疏水性空腔结合时, 产生较好的对映选择性, 邻位取代的 2 -硝基- $\beta$-硝基苯乙烯比对位取代的 4硝基- $\beta$-硝基苯乙烯 ee 值更高, 通过量子化学优化计算证实空间位阻效应. 应用 2 -金刚烷酮与 $\beta$-环糊精衍生物空腔形成竞 争性的包结反应实验, 产物产率和 ee 值都下降, 说明 $\beta$-环糊精衍生物的疏水性空腔是产生不对称诱导和催化活性不可或缺 的部分, 底物分子与 $\beta$-环糊精衍生物的包结过程通过 $2 \mathrm{D}-{ }^{1} \mathrm{H}$ ROESY NMR 和紫外吸收图谱获得确认. 其中 $L-2$-氨甲基吡咯 烷修饰 $\beta$-环糊精 CD-1 表现出较好的反应对映选择性, 在溶剂 $\left(\mathrm{pH}=7.5,0.5 \mathrm{~mol} / \mathrm{L} \mathrm{CH}_{3} \mathrm{COONa}-\mathrm{HCl}\right) 2 \mathrm{~mL}$, 环己酮 $2 \mathrm{mmol}$, 2-硝基- $\beta$-硝基苯乙烯 $0.2 \mathrm{mmol}, \mathrm{CD}-1$ 用量 $0.04 \mathrm{mmol}, 25^{\circ} \mathrm{C}$ 反应 $96.0 \mathrm{~h}$ 的条件下, 环己酮与 2-硝基- $\beta$-硝基苯乙烯 Michael 加成产物的 ee 值达 $71 \%$, 产率为 $47 \%$. 该反应过程在 $\beta$-环糊精衍生物的疏水性空腔内进行, 修饰基团 $L-2$-氨甲基吡咯烷与 环己酮形成烯胺的催化反应.

关键词: $\beta$-环糊精; 修饰; 不对称麦克尔加成; 量子化学计算

收稿日期: 2016-03-11. 接受日期: 2016-04-24. 出版日期: 2016-08-05.

*通讯联系人. 电话: (020)84113658; 传真: (020)84113654; 电子信箱: jihb@mail.sysu.edu.cn

基金来源: 国家自然科学基金 (21425627, 21376279).

本文的英文电子版由Elsevier出版社在ScienceDirect上出版(http://www.sciencedirect.com/science/journal/18722067). 